\title{
Access Assured: A Pilot Program to Finance Primary Care for Uninsured Patients Using a Monthly Enrollment Fee
}

\author{
John W. Saultz, MD, David Brown, BA, Stephen Stenberg, BA, \\ Rebecca E. Rdesinski, MSW, MPH, Carrie J. Tillotson, MPH, Danielle Eigner, DO, and \\ Jennifer DeVoe, MD, DPhil
}

Background: Access Assured is an experimental program being used by 2 academic family medicine practices to deliver primary care to an uninsured patient population using a monthly retainer payment system in addition to a sliding fee schedule for office visits. This prospective cohort study was designed to determine whether patients would join such a program, to describe the population of people who did so, and to assess the program's financial viability.

Methods: We used data abstracted from our electronic medical record system to describe the demographic characteristics and care utilization patterns of those patients enrolling during the first year of the study, between February 1, 2008, and January 31, 2009. We also compared 2 subpopulations of enrollees defined by their eligibility for office fee discounts based on income.

Results: A total of 600 Access Assured members made 1943 office visits during the study period, receiving a total of 4538.22 relative value units of service. Based on the membership fee, office visit fee collections, and remaining accounts receivable, this resulted in an expected reimbursement rate of $\$ 42.88$ per relative value units. Three hundred one of the $600(50.2 \%)$ patients had incomes above $400 \%$ of the federal poverty level (FPL) at the time of each of their office visits and were therefore not eligible for any visit fee discount. Another 156 patients (26.0\%) were eligible for a $100 \%$ discount of all visit fees based on their income below $200 \%$ of the FPL. Using a multivariable Poisson regression analysis of these 2 groups, we determined that age was a significant determinant of return visit rate, with a $0.7 \%$ increase in return visit rate for each additional year of age $(P=.006)$. Women had a $26 \%$ higher return visit rate than men $(P=.001)$. After accounting for age, sex, and clinic site, fee discount level based on income was not a significant independent determinant of return visit rate $(P=.118)$.

Conclusions: A retainer-based program to enroll uninsured patients being used in 2 academic family medicine clinics attracted 600 patients during its first year. The program was financially viable and resulted in an expansion of our service to uninsured patients. More than half of the patients had incomes above $400 \%$ of the FPL, suggesting that the population of uninsured Oregonians may be economically more diverse than suspected. (J Am Board Fam Med 2010;23:393-401.)

Keywords: Access to Health Care, Uninsured, Health Care Financing

This article was externally peer reviewed.

Submitted 7 September 2009; revised 7 January 2010; accepted 11 January 2010.

From the Department of Family Medicine (JWS, DB, SS, RER, DE, JD) and the Oregon Clinical and Translational Research Institute (CJT), Oregon Health \& Science University, Portland.

Funding: The Oregon Health \& Science University's Department of Family Medicine Research Program supported this study.

Conflict of interest: none declared.

Corresponding author: John W. Saultz, MD, Department of Family Medicine, Oregon Health \& Science University, 3181 SW Sam Jackson Park Road, Mail Code: FM, Portland, OR 97239 (E-mail: saultz@ohsu.edu).
The combined effects of a severe economic recession, continued growth of health care costs, and cuts in Medicaid benefits have contributed to a rapid increase in the number of Americans without health insurance. ${ }^{1,2}$ In 2007, health care costs averaged $\$ 7421$ per person in the United States, with an increasing portion of this cost shifting directly to consumers. ${ }^{3}$ Access to care among uninsured adults, particularly those with chronic health conditions, deteriorated between 1997 and 2006, ${ }^{4}$ and this trend has probably worsened during the past 2 years. In Oregon, the rate of uninsured reached 
$16.8 \%$ in 2007 and is almost certainly worse in $2010 .^{5}$

Although the lack of health insurance is a substantial barrier to the access of basic health care, ${ }^{6}$ there is good evidence that uninsured people have better self-reported access to care when they are able to receive basic primary care services. ${ }^{7}$ From the perspective of the family physician, providing care to people without health insurance can threaten the financial viability of a practice, placing clinicians in the difficult position of either denying care to people who need it or caring for patients with insufficient revenue to cover the cost of practice. ${ }^{8}$ Under these conditions, physicians often limit the availability of appointments for uninsured people or charge such patients for each service provided, requiring substantial cash payment at the time of service.

On the other end of the economic spectrum, many practices have experimented with retainer or boutique payment models to offer expanded services, usually to insured patients..$^{9-12}$ For example, one retainer practice model charges patients a monthly fee in addition to the usual per-visit charges in exchange for services such as house calls, accompanied specialty visits, email access to the physician, and enhanced after-hours access. ${ }^{9}$ This model allows for enhanced revenue to support the expansion of non-office visit services, which are appealing to many consumers. Retainer or boutique practices have been featured in articles in the lay press ${ }^{13}$ and in professional news sources, ${ }^{14}$ and these types of practice models have grown to the point that an organization, the Society for Innovative Practice Design, has formed to represent them. ${ }^{15}$ In addition, medical professional organizations including the American Medical Association ${ }^{16}$ and the American Academy of Family Physicians ${ }^{17}$ have published ethical guidelines for such practices.

Providing retainer services to commercially insured patients requires a careful process of compliance with commercial insurance contracts, but there is no such restriction on retainer practice for those without insurance. To our knowledge, the retainer practice model has rarely been used specifically to care for uninsured people and such a model has not been described in the literature. This article describes the first year of a cohort study designed to examine an experimental program using a retainer payment system in addition to a sliding fee schedule for office visits to deliver pri- mary care to a population of uninsured people. The study objectives included (1) to determine whether patients will join such a program, (2) to describe the population of people who enroll, and (3) to determine whether the revenues collected from such a program could cover the costs of providing care in this way.

\section{Methods}

In December 2007, Oregon Health and Science University (OHSU) adopted a charity policy for all its ambulatory care clinics that featured a generous sliding fee schedule for office visits. The policy requires a financial needs assessment at the time of each visit for all patients without health insurance. Based on this assessment, visits are provided at a graduated discount rate for patients with incomes up to $400 \%$ of the federal poverty level (FPL; $\$ 84,800$ for a family of 4$)$. Below this income level, the fees for all charges are discounted from $10 \%$ (for those between $385 \%$ and $400 \%$ of the FPL) up to $100 \%$ for patients with incomes below $200 \%$ of the FPL (\$42,400 for a family of 4). Because of the high demand for family medicine in our community, we were resistant to the idea of limiting access to uninsured patients found it impossible to financially manage our clinics if we could not determine the discount level before delivering services. Thus, we chose to create a new program called Access Assured that would allow us to provide services without always requiring office visits. We have carefully studied this program from its inception and present the first year of data in this article.

\section{Access Assured}

Beginning on February 1, 2008, all uninsured patients requesting appointments in 2 family medicine clinics operated by the OHSU Department of Family Medicine (South Waterfront and Gabriel Park) were advised that appointments were only available if they were insured by a health plan that contracted with our practice or if they joined the Access Assured program. Joining Access Assured required each person to pay a fee of $\$ 25$ per month for a minimum of 6 months (\$150), and we provided a $\$ 25$ discount for those who chose to enroll for 12 months, thus enabling them to pay $\$ 275$ for a full year of membership. Patients that were already enrolled in the practice were allowed to join for only 3 months as a trial membership. Patients 
who chose not to pay this fee were directed to safety net practices in the area, including a free clinic staffed by members of our department.

Access Assured members were then allowed to schedule as many office appointments as they wanted and to use our 24-hour telephone triage line, asynchronous secure email access to their physicians, and our prescription refill system. The members were given a written description of the program and they were instructed that their membership fee did not cover any other services (eg, prescription drugs, specialist visits, laboratory or radiograph charges). They were further instructed that they would be charged a fee for each visit as determined by the sliding fee schedule described above. Thus, a full visit fee was charged for members above $400 \%$ of the FPL and there was no visit charge for those below 200\% of the FPL. This discount level was determined at the time of each visit. We appointed one of our existing accounting staff to manage this program and kept accurate records of Access Assured members on a daily basis. We provided care for one month after membership expired for those patients who chose not to reenroll in the program and we carefully tracked re-enrollment as each membership period expired.

\section{Data Collection}

Both of the participating clinics were fully operational with the Epic electronic health record (Epic Systems Corp., Verona, WI) throughout the study period. At the end of the 12-month study period (February 1, 2009), we abstracted information from the electronic record for every patient who was or had been an Access Assured member at any point during this study period. This information included demographic data accurate as of February 1, 2009 (such as age, home zip code, and sex), financial information about charges and collections for visits and other office services, and detailed information about each visit and telephone encounter. These data were de-identified and transferred into a secure research database. We then analyzed only information that occurred during days of enrollment in Access Assured because many patients were members of Access Assured for only part of the year. Members of the research team had access to only de-identified data. The Institutional Review Board at OHSU approved our study protocol.

\section{Data Management and Statistical Analyses}

Basic descriptive statistics were used to describe the entire patient population and the population's utilization patterns. Once we had this descriptive information it became clear that the population fell into 3 distinct subpopulations in terms of eligibility for fee discounts at each visit: (1) those for whom all visits were at the $0 \%$ discount level; (2) those for whom all visits were at the $100 \%$ discount level; and (3) those who did not fall into one of the first 2 groups. We then conducted a post hoc analysis to examine differences in care utilization, including return visit count, telephone encounters, and specialty referrals, between the first and second of these subpopulations.

Because all but 12 of the 600 Access Assured members did not officially become members of the program until they made their initial office visit, most members had at least one visit. Therefore, in this comparison we analyzed return visits rather than total visits as our measure of utilization. Univariable comparisons were conducted using independent samples $t$ tests and Wilcoxon rank-sum tests for continuous variables where appropriate; $\chi^{2}$ tests were used for categorical variables. Because visit count data often have a Poisson distribution and because the number of months enrolled varied across patients, a Poisson regression analysis was used to describe differences in return visit rate between these 2 discount-level groups. This model seeks to compare the rate of return visits per enrollee-month between groups, adjusting for age, sex, and the clinic in which care was received. Reported $P$ values are 2 -tailed and are considered significant at $P<.05$.

\section{Results}

A total of 600 people were members of Access Assured at some point during the study period. These 600 people paid Access Assured membership fees totaling \$70,325. Access Assured members made a total of 1943 office visits, resulting in $\$ 333,869.78$ in visit charges. By the end of the 12-month study period, we had collected $\$ 30,320.01$ from these charges, $\$ 209,596.10$ was discounted from the charges because of the sliding fee scale, and $\$ 93,953.67$ remained as accounts receivable as of February 1, 2009. We provided a total of 4538.22 relative value units (RVUs) of service during these office visits, resulting in an 
Figure 1. Histogram of enrollment duration in months for 600 Access Assured members (mean, 5.20 months [SD, 2.45 months]).

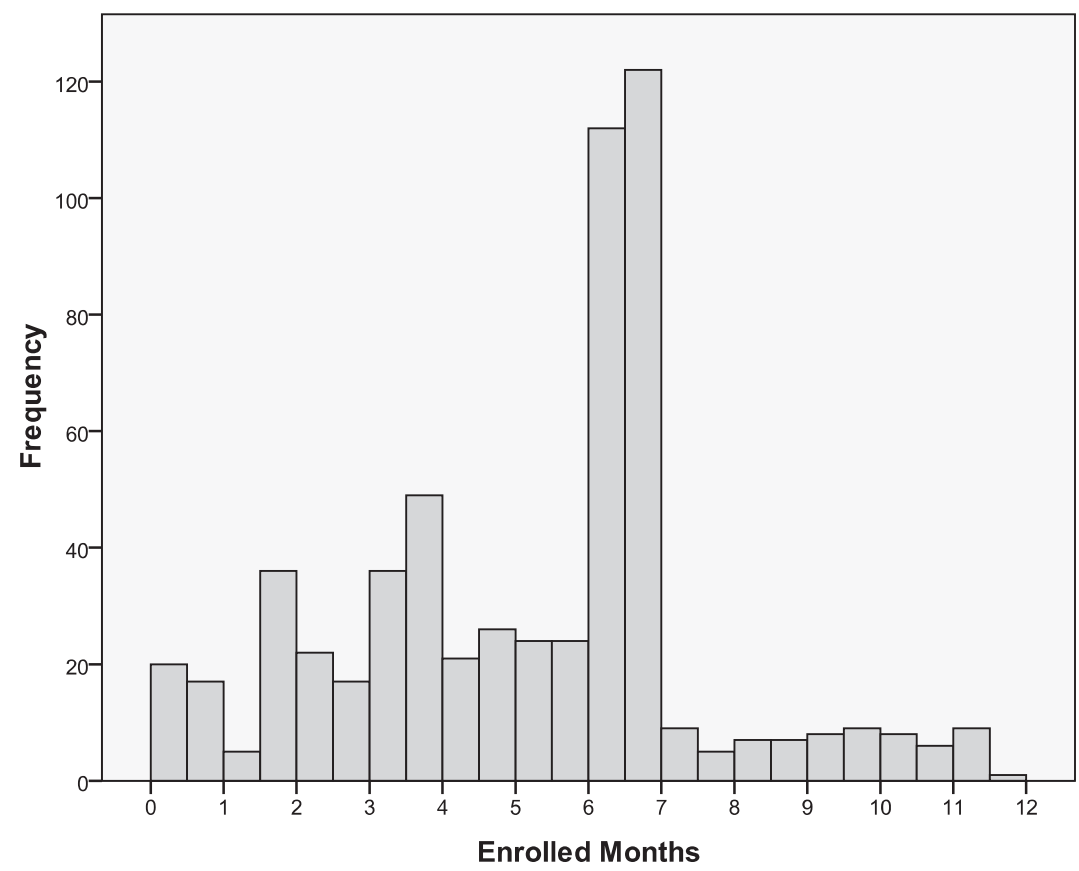

expected reimbursement rate of $\$ 42.88$ per RVU based on the membership fee, collections, and remaining accounts receivable. The reimbursement rate was $\$ 22.18$ per RVU (counting only cash in hand from the membership fee and collections) and was $\$ 15.50$ per RVU based on membership fees alone.

Figure 1 indicates the number of enrolled months for the 600 members in the cohort. Table 1 characterizes the enrolled members and their use of services during the study period. MyChart is the feature of the EPIC electronic health record that allows asynchronous, internet-based, secure communication between patients and providers. Thirty percent of the Access Assured patients utilized this service at some time during the study period.

As shown in Table 1, we observed that nearly $90 \%$ of visits were by patients who fell into the 2 subpopulations on opposite ends of the income spectrum: $49 \%$ by those earning $>400 \%$ FPL and $41 \%$ by those earning $<200 \%$ FPL. The group in the middle, earning between $200 \%$ to $400 \%$ FPL, and those with unknown earnings represented only $10 \%$ of total visits. A total of 301 of the 600 patients $(50.2 \%)$ had incomes above $400 \%$ of the FPL at each of their office visits and were therefore not eligible for any fee discount for any of their visits. Another 156 patients (26.0\%) were eligible for a $100 \%$ discount of all fees during their entire period of enrollment based on their income levels. The remaining 143 patients (23.8\%) had visits with more than one level of discount because their incomes changed during the year $(\mathrm{n}=98)$, their discount level was between $10 \%$ and $90 \%(\mathrm{n}=8)$, or the discount level information was not recorded $(\mathrm{n}=37$, including 12 patients who had no visits). Table 2 reflects a comparison of the demographic makeup and utilization patterns of the first 2 of these groups. This analysis suggests that the higher income group was significantly younger; more likely to attend the Gabriel Park clinic; and had significantly fewer return visits, telephone encounters, and specialty referrals.

Table 3 reflects a multivariable Poisson regression analysis of these 2 groups. Age was a significant determinant of return visit rate, with a $0.7 \%$ increase in return visit rate for each additional year of age $(P=.006)$. On average and while adjusting for other covariates, 25 -year-old patients had 0.30 return visits per enrollee-month (95\% CI, $0.20-0.31$ ), whereas 75 -year-old patients had 0.43 return visits per enrollee-month (95\% CI, 0.35 $0.50)$. Women had a $26 \%$ higher return visit rate than men $(P=.001)$, and patients receiving care at the South Waterfront clinic had a $31 \%$ higher return visit rate than those receiving care at Gabriel Park $(P=.001)$. After accounting for age, sex, and 
Table 1. Demographic and Care Utilization Data of Access Assured Members

\begin{tabular}{|c|c|}
\hline Enrollees (n) & 600 \\
\hline Total enrollee months (n) & 3121 \\
\hline \multicolumn{2}{|l|}{ Age (years)* } \\
\hline Mean (SD) & $40.6(15.3)$ \\
\hline Range & $0-83$ \\
\hline \multicolumn{2}{|l|}{$\operatorname{Sex}(\mathrm{n}[\%])$} \\
\hline Female & $344(57.3)$ \\
\hline Male & $256(42.7)$ \\
\hline Total visits (n) & 1943 \\
\hline Total visits per total enrollee months (n) & 0.62 \\
\hline \multicolumn{2}{|l|}{ Total visits by clinic (n [\%]) } \\
\hline South Waterfront & $1327(68.3)$ \\
\hline Gabriel Park & $616(31.7)$ \\
\hline Return visits, excluding first visit (n) & 1353 \\
\hline \multicolumn{2}{|l|}{$\begin{array}{l}\text { Return visits per enrollee person-month } \\
\text { (excluding first visit) }\end{array}$} \\
\hline Mean (SD) & $0.43(0.57$ \\
\hline Median & 0.26 \\
\hline Range & $0-4.81$ \\
\hline \multicolumn{2}{|l|}{ Discount level (\%), by visit ${ }^{\dagger}$} \\
\hline 0 & $950(48.89)$ \\
\hline 10 & $0(0)$ \\
\hline 20 & $1(0.05)$ \\
\hline 30 & $0(0)$ \\
\hline 40 & $1(0.05)$ \\
\hline 50 & $1(0.05)$ \\
\hline 60 & $2(0.10)$ \\
\hline 70 & $12(0.62)$ \\
\hline 80 & $25(1.29)$ \\
\hline 90 & $31(1.60)$ \\
\hline 100 & $795(40.92)$ \\
\hline Missing & $125(6.43)$ \\
\hline Total & $1943(100.00)$ \\
\hline Total telephone encounters (n) & 1173 \\
\hline $\begin{array}{l}\text { Total telephone encounters per total enrollee } \\
\text { months }\end{array}$ & 0.38 \\
\hline Total specialty referrals & 379 \\
\hline $\begin{array}{l}\text { Total specialty referrals per total enrollee } \\
\text { months }\end{array}$ & 0.12 \\
\hline \multicolumn{2}{|l|}{ MyChart status (n [\%]) } \\
\hline Activated & $180(30.0)$ \\
\hline $\begin{array}{l}\text { Access code generated first time but not } \\
\text { used }\end{array}$ & $140(23.3)$ \\
\hline Inactivated & $12(2.0)$ \\
\hline Never activated & $268(44.7)$ \\
\hline
\end{tabular}

*For any patients $<1$ year old, age was recorded as 0 .

${ }^{\dagger}$ Data provided for discount by visit shown as number (\%) of visits.

clinic site, fee discount level was not a significant independent determinant of return visit rate $(P=$ $.118)$; there was an average of 0.32 return visits per enrollee-month (95\% CI, 0.29-0.34) among the $0 \%$ discount group and 0.35 return visits per enrollee-month (95\% CI, $0.31-0.40$ ) for the $100 \%$ discount group.

Table 4 lists the 10 most common primary visit diagnoses of the 3 subpopulations based on discount level (includes the subpopulation of Access Assured members not in the first 2 groups). Acute problems (back pain, respiratory symptoms); chronic problems (hyperlipidemia, hypertension); and behavioral problems (depression, anxiety, and substance abuse) appear on all 3 lists, but behavioral problems were more prominent in the group with no fee discount whereas chronic medical conditions were more prominent in the group eligible for a $100 \%$ discount throughout their enrollment. We did not analyze these differences for statistical significance.

\section{Discussion}

Our first objective was to determine whether patients would enroll in this new program. The 600 people who enrolled represent 50 new patients per month at the 2 participating clinics. Although we did not have a specific target, this number reflects a substantial number of new patients, particularly when one considers that both practices were quite busy before the program began.

We anticipated that most patients seeking Access Assured membership would be low-income, uninsured people who were ineligible for Medicaid. Instead, the majority (just more than 50\%) of those enrolled during this first year had incomes above $400 \%$ of the FPL for the entire study period. All patients in this program had a relatively high frequency of office visits, which may be because of the phenomenon of increased care utilization by previously uninsured patients when they obtain access to care. ${ }^{18,19}$ Selection bias may also have contributed to this phenomenon if patients with more health problems or concerns were more likely to sign up for the program compared with healthier patients.

As expected, we found that older patients used care more often than younger ones, and women sought care more often than men. We cannot explain the difference in utilization between the 2 participating clinics, which are similar in size, clinician characteristics, and overall patient payer mix. Somewhat surprisingly, patients eligible for a $100 \%$ 
Table 2. Comparison of $0 \%$ and 100\% Discount Level Subpopulations of Access Assured Members $(\mathrm{n}=457)$

\begin{tabular}{|c|c|c|c|c|c|c|c|c|c|}
\hline & \multicolumn{4}{|c|}{$0 \%$ Discount Level (by Person)* } & \multicolumn{4}{|c|}{$100 \%$ Discount Level (by Person) ${ }^{\dagger}$} & \multirow[b]{2}{*}{$P$} \\
\hline & Mean (SD) & Median & Range & n (\%) & Mean (SD) & Median & Range & n (\%) & \\
\hline Age (years) ${ }^{\ddagger}$ & $37.2(14.8)$ & 36 & $0-73$ & & $46.1(13.6)$ & 50 & $1-80$ & & $<.001$ \\
\hline Months enrolled ${ }^{\S}$ & $5.02(2.50)$ & 5.81 & $0-11.2$ & & $5.13(2.44)$ & 5.67 & $0.26-11.53$ & & .913 \\
\hline Sex & & & & & & & & & .293 \\
\hline Female & & & & $162(53.8)$ & & & & $92(59.0)$ & \\
\hline Male & & & & $139(46.2)$ & & & & $64(41.0)$ & \\
\hline Clinic & & & & & & & & & $<.001$ \\
\hline South Waterfront & & & & $165(54.8)$ & & & & $124(79.5)$ & \\
\hline Gabriel Park & & & & $129(42.9)$ & & & & $30(19.2)$ & \\
\hline Data missing & & & & $7(2.3)$ & & & & $2(1.3)$ & \\
\hline $\begin{array}{l}\text { Return visits per enrollee month } \\
\text { (excluding first visit) }\end{array}$ & $0.32(0.47)$ & 0.15 & $0-3.38$ & & $0.42(0.47)$ & 0.3 & $0-4.81$ & & .004 \\
\hline $\begin{array}{l}\text { Telephone encounters per } \\
\text { enrollee month }\end{array}$ & $0.32(0.88)$ & 0 & $0-10.15$ & & $0.41(0.79)$ & 0.17 & $0-8.01$ & & .005 \\
\hline $\begin{array}{l}\text { Specialty referrals per enrollee } \\
\text { month }\end{array}$ & $0.09(0.29)$ & 0 & $0-3.38$ & & $0.25(0.48)$ & 0.1 & $0-3.38$ & & $<.001$ \\
\hline
\end{tabular}

$*^{n}=301 ; 65.9 \%$.

${ }^{+} \mathrm{n}=156 ; 34.1 \%$.

${ }^{\ddagger}$ For any individuals $<1$ year old, age was recorded as 0 .

${ }^{\S}$ For any individual enrolled $<1$ month, months enrolled was recorded as 0 .

fee discount (who may have gone longer periods without access) did not have higher return visit utilization rates than those with no discount after controlling for age, sex, and clinic attended. We were also surprised to note that only $30 \%$ of the patients in this program used the EPIC MyChart program to initiate secure, internet-based, electronic communication with their providers, even

Table 3. Results of Poisson Multiple Regression Analysis Comparing Return Visits per Enrollee Month by Access Assured Members in 0\% and 100\% Discount Groups

\begin{tabular}{|c|c|c|c|}
\hline $\begin{array}{l}\text { Return Visits per Enrollee Month } \\
\text { (Excluding First Visit) }\end{array}$ & $\begin{array}{c}\text { Incidence Rate Ratio } \\
(95 \% \mathrm{CI})\end{array}$ & $P^{*}$ & $\begin{array}{c}\text { Estimated Mean Return Visit } \\
\text { Rate }^{\dagger}(95 \% \text { CI })\end{array}$ \\
\hline \multicolumn{4}{|l|}{ Discount level (\%) } \\
\hline 0 & $1.00^{\ddagger}$ & - & $0.32(0.29-0.34)$ \\
\hline 100 & $1.12(0.97-1.30)$ & .118 & $0.35(0.31-0.40)$ \\
\hline Age (years) & $1.007(1.002-1.012)^{\S}$ & .006 & - \\
\hline 25 & - & - & $0.30(0.26-0.34)$ \\
\hline 50 & - & - & $0.36(0.33-0.39)$ \\
\hline 75 & - & - & $0.43(0.35-0.50)$ \\
\hline \multicolumn{4}{|l|}{ Sex } \\
\hline Male & $1.00^{\|}$ & - & $0.30(0.26-0.33)$ \\
\hline Female & $1.26(1.10-1.45)$ & .001 & $0.37(0.34-0.41)$ \\
\hline \multicolumn{4}{|l|}{ Clinic } \\
\hline Gabriel Park & $1.00^{\mathbb{I I}}$ & - & $0.29(0.25-0.33)$ \\
\hline South Waterfront & $1.31(1.12-1.54)$ & .001 & $0.38(0.35-0.41)$ \\
\hline
\end{tabular}

All results are adjusted for each of the covariates listed in the first column.

${ }^{*} P$ values were obtained by the Wald $\chi^{2}$ test for Poisson regression.

${ }^{\dagger}$ Estimated mean return visit rates were calculated while holding covariates constant at their average values.

${ }^{\text {f }}$ Reference group is the $0 \%$ discount level.

${ }^{\S}$ Incidence rate ratio is for every 1 -year increase in age.

"Reference group is men.

"Reference group is the Gabriel Park clinic. 
Table 4. Ten Most Common Diagnoses During Visits of Access Assured Members

\begin{tabular}{|c|c|c|c|c|c|c|c|c|c|}
\hline Rank & $\mathrm{n}$ & $\begin{array}{c}\text { Total } \\
\text { Diagnoses } \\
(\%)\end{array}$ & $0 \%$ Discount Level* & $\mathrm{n}$ & $\begin{array}{l}\text { Total } \\
\text { Diagnoses } \\
(\%)\end{array}$ & $\begin{array}{l}\text { 100\% Discount } \\
\text { Level }^{+}\end{array}$ & $\mathrm{n}$ & $\begin{array}{l}\text { Total } \\
\text { Diagnoses } \\
(\%)\end{array}$ & $\begin{array}{c}\text { Missing, } \\
0 \%<\mathrm{x}<100 \% \text {, or } \\
\text { Multidiscount Level }^{\ddagger}\end{array}$ \\
\hline 1 & 43 & 3.8 & Depressive disorder & 28 & 3.7 & $\begin{array}{l}\text { Disorders of lipoid } \\
\text { metabolism }\end{array}$ & 34 & 4.1 & General symptoms \\
\hline 2 & 38 & 3.3 & General symptoms & 27 & 3.6 & $\begin{array}{l}\text { Other and } \\
\text { unspecified back } \\
\text { disorders }\end{array}$ & 24 & 2.9 & $\begin{array}{l}\text { Other and unspecified } \\
\text { joint disorders }\end{array}$ \\
\hline \multirow[t]{2}{*}{3} & \multirow[t]{2}{*}{35} & \multirow[t]{2}{*}{3.1} & \multirow{2}{*}{$\begin{array}{l}\text { Anxiety, dissociative, and } \\
\text { somatoform disorders }\end{array}$} & 24 & 3.2 & General symptoms & \multirow[t]{2}{*}{22} & \multirow[t]{2}{*}{2.6} & \multirow{2}{*}{$\begin{array}{l}\text { Symptoms involving } \\
\text { respiratory system } \\
\text { and other chest } \\
\text { symptoms }\end{array}$} \\
\hline & & & & 24 & 3.2 & $\begin{array}{l}\text { Essential } \\
\text { hypertension }\end{array}$ & & & \\
\hline \multirow[t]{2}{*}{4} & 28 & 2.5 & $\begin{array}{l}\text { Other and unspecified } \\
\text { back disorders }\end{array}$ & \multirow[t]{2}{*}{23} & \multirow[t]{2}{*}{3.1} & $\begin{array}{l}\text { Special } \\
\text { investigations }\end{array}$ & \multirow[t]{2}{*}{20} & \multirow[t]{2}{*}{2.4} & \multirow{2}{*}{$\begin{array}{l}\text { Other symptoms } \\
\text { involving abdomen } \\
\text { and pelvis }\end{array}$} \\
\hline & 28 & 2.5 & Essential hypertension & & & $\begin{array}{l}\text { and } \\
\text { examinations }\end{array}$ & & & \\
\hline 5 & 26 & 2.3 & $\begin{array}{l}\text { Symptoms involving } \\
\text { respiratory system and } \\
\text { other chest symptoms }\end{array}$ & 21 & 2.8 & $\begin{array}{l}\text { General medical } \\
\text { examination }\end{array}$ & 18 & 2.1 & Essential hypertension \\
\hline \multirow[t]{4}{*}{6} & \multirow[t]{4}{*}{25} & \multirow[t]{4}{*}{2.2} & \multirow[t]{4}{*}{$\begin{array}{l}\text { Nondependent abuse of } \\
\text { drugs }\end{array}$} & \multirow[t]{4}{*}{20} & \multirow[t]{4}{*}{2.7} & \multirow{4}{*}{$\begin{array}{l}\text { Special screening } \\
\text { for malignant } \\
\text { neoplasms }\end{array}$} & 17 & 2.0 & $\begin{array}{l}\text { Nondependent abuse } \\
\text { of drugs }\end{array}$ \\
\hline & & & & & & & 17 & 2.0 & $\begin{array}{l}\text { Anxiety, dissociative, } \\
\text { and somatoform } \\
\text { disorders }\end{array}$ \\
\hline & & & & & & & 17 & 2.0 & $\begin{array}{l}\text { Need for prophylactic } \\
\text { vaccination and } \\
\text { inoculation against } \\
\text { certain diseases }\end{array}$ \\
\hline & & & & & & & 17 & 2.0 & $\begin{array}{l}\text { Disorders of lipoid } \\
\text { metabolism }\end{array}$ \\
\hline \multirow[t]{2}{*}{7} & 24 & 2.1 & Diabetes mellitus & \multirow[t]{2}{*}{17} & \multirow[t]{2}{*}{2.3} & \multirow{2}{*}{$\begin{array}{l}\text { Other and } \\
\text { unspecified joint } \\
\text { disorders }\end{array}$} & \multirow[t]{2}{*}{16} & \multirow[t]{2}{*}{1.9} & \multirow{2}{*}{$\begin{array}{l}\text { Other soft tissue } \\
\text { disorders }\end{array}$} \\
\hline & 24 & 2.1 & $\begin{array}{l}\text { Other symptoms involving } \\
\text { abdomen and pelvis }\end{array}$ & & & & & & \\
\hline \multirow[t]{2}{*}{8} & \multirow[t]{2}{*}{22} & \multirow[t]{2}{*}{1.9} & \multirow[t]{2}{*}{ Asthma } & 15 & 2.0 & $\begin{array}{l}\text { Depressive } \\
\text { disorder }\end{array}$ & \multirow[t]{2}{*}{14} & 1.7 & $\begin{array}{l}\text { Special screening for } \\
\text { malignant }\end{array}$ \\
\hline & & & & 15 & 2.0 & Diabetes mellitus & & & neoplasms \\
\hline 9 & 21 & 1.9 & $\begin{array}{l}\text { Special screening for } \\
\text { malignant neoplasms }\end{array}$ & 14 & 1.9 & $\begin{array}{l}\text { Other symptoms } \\
\text { involving } \\
\text { abdomen and } \\
\text { pelvis }\end{array}$ & 13 & 1.6 & $\begin{array}{l}\text { General medical } \\
\text { examination }\end{array}$ \\
\hline & & & & 14 & 1.9 & $\begin{array}{l}\text { Special screening } \\
\text { for endocrine, } \\
\text { nutritional, }\end{array}$ & 13 & 1.6 & $\begin{array}{l}\text { Symptoms involving } \\
\text { urinary system }\end{array}$ \\
\hline & & & & & & $\begin{array}{l}\text { metabolic, and } \\
\text { immunity } \\
\text { disorders }\end{array}$ & 13 & 1.6 & $\begin{array}{l}\text { Other and unspecified } \\
\text { back disorders }\end{array}$ \\
\hline 10 & 19 & 1.7 & $\begin{array}{l}\text { Other and unspecified } \\
\text { joint disorders }\end{array}$ & 13 & 1.7 & $\begin{array}{l}\text { Other soft tissue } \\
\text { disorders }\end{array}$ & 12 & 1.4 & Diabetes mellitus \\
\hline & 19 & 1.7 & $\begin{array}{l}\text { Symptoms involving skin } \\
\text { and other } \\
\text { integumentary tissue }\end{array}$ & 13 & 1.7 & $\begin{array}{l}\text { Symptoms } \\
\text { involving } \\
\text { respiratory }\end{array}$ & & & \\
\hline & 19 & 1.7 & Other soft tissue disorders & & & system and & & & \\
\hline & 19 & 1.7 & $\begin{array}{l}\text { Need for prophylactic } \\
\text { vaccination and } \\
\text { inoculation against } \\
\text { certain diseases }\end{array}$ & & & symptoms & & & \\
\hline & 19 & 1.7 & $\begin{array}{l}\text { Disorders of lipoid } \\
\text { metabolism }\end{array}$ & & & & & & \\
\hline
\end{tabular}

${ }^{*} \mathrm{n}=256$ different diagnoses; $\mathrm{n}=1135$ total diagnoses.

${ }^{\dagger} \mathrm{n}=216$ different diagnoses; $\mathrm{n}=747$ total diagnoses.

${ }^{{ }_{\mathrm{n}}} \mathrm{n}=249$ different diagnoses; $\mathrm{n}=838$ total diagnoses. 
though MyChart was free to them as members of Access Assured.

At the 12-month mark, we estimated revenue from the program to be $\$ 42.88$ per RVU based on the membership fees, collections, and remaining accounts receivable. Interestingly, the reimbursement rate from all of these payment sources combined was higher than Medicare rates (\$38 per RVU) and Medicaid rates ( $\$ 34$ per RVU) in Oregon. Because these financial calculations included more than just the monthly membership fee, our results should be interpreted with caution by those considering a similar program based on retainer fees alone. The administration of this program required additional work by the managers of the 2 clinics and by the office staff who collected the membership fees and explained the program to patients. We did not add staff to administer the program but instead asked existing staff to absorb this workload, so we did not add any new costs specifically for this program.

Previous studies of retainer practices operating as supplements to insurance plans have suggested that physicians in such practices were less likely to accept Medicaid patients, but $84 \%$ of the physicians in such practices were providing charity care in some form. ${ }^{9}$ Previous reports have addressed ethical concerns about retainer practices and guidelines have been published for such programs. ${ }^{14,16,17}$ We adhered to these guidelines closely and, by the end of the program's first year, there was widespread support for the program among our providers, staff, and patients based on anecdotal reports and day-to-day experience.

\section{Limitations}

Our study is the first to report a retainer-based payment system exclusively for uninsured patients. It is also our team's first experience with using data abstracted from our electronic health records to study a payment model. In addition to limitations inherent in these pioneering endeavors, this study is limited by its short duration. We chose a relatively short study period because we needed a basic proof of concept before we could decide to adopt the Access Assured model as an ongoing addition to our scope of community service. Thus, at the time of this first assessment many of the Access Assured members had only been in the program a few months. As a result, we are unable to report on re-enrollment rates and had a short time frame in which to conduct visit frequency and utilization analyses. We can report that the program generated few patient complaints, and we received numerous statements of appreciation and word-ofmouth referrals from the patients in this program. We are currently conducting a qualitative analysis of the program based on telephone interviews with current and former members and plan to repeat our economic analysis of the program after 2 years.

\section{Conclusions}

A retainer-based program to enroll uninsured patients in 2 academic family medicine clinics resulted in a program that attracted 600 patients during its first year. The program was financially viable and resulted in our ability to expand service to uninsured Oregonians. We were surprised that more than half of the patients had incomes above $400 \%$ of the FPL, suggesting that the population of uninsured Oregonians may be economically more diverse than we suspected. It may be that the problem of patients having no insurance will be solved by national or regional health care reform. If not, our preliminary analysis suggests that a direct retainer payment program may be a viable model for serving the uninsured.

\section{References}

1. Institute of Medicine. America's uninsured crisis: consequences for health and health care. Available at http://www.iom.edu/Reports/2009/Americas-Uninsured-Crisis-Consequences-for-Health-and-HealthCare.aspx. Accessed 5 December 2009.

2. Iglehart JK. Medicaid revisited-skirmishes over a vast public enterprise. N Engl J Med 2007;356:73440 .

3. Hartman M, Martin A, McDonnell P, Catlin A, National Health Expenditure Accounts Team. National health spending in 2007: slower drug spending contributes to lowest rate of overall growth since 1998. Health Aff (Millwood) 2009;28:246-61.

4. Hoffman C, Schwartz K. Eroding access among nonelderly US adults with chronic conditions: ten years of change. Health Affairs (Millwood) 2008;27: w340-8.

5. Casey J. Number of uninsured in Oregon holds steady. Available at http://www.oregonlive.com/ news/index.ssf/2008/08/number_of_uninsured_in_ oregon.html. Accessed 24 August 2009.

6. Asplin BR, Rhodes KV, Levy $\mathrm{H}$, et al. Insurance status and access to urgent ambulatory care follow-up appointments. JAMA 2005;294:1248-54.

7. Stewart AL, Grumbach K, Osmond DH, Vranizan K, Komaromy M, Bindman AB. Primary care and 
patient perceptions of access to care. J Fam Pract 1997;44:177-85.

8. Bodenheimer T. Primary care-will it survive? N Engl J Med 2006;355:861-6.

9. Alexander GC, Kurtlander J, Wynia MK. Physicians in retainer ("concierge") practice: a national survey of physician, patient, and practice characteristics. J Gen Intern Med 2005;20:1079-83.

10. Linz AJ, Halas PF, Fallon LF, Metz RJ. Impact of concierge care on healthcare and clinical practice. J Am Osteopath Assoc 2005;105:515-20.

11. Brennan TA. Luxury primary care- market innovation or threat to access? N Engl J Med 2002;346: 1165-8.

12. Reinhardt UE. The emergence of "boutique medicine.” BMJ USA 2002;2:468.

13. Zuger A. For a retainer, lavish care by "boutique doctors.” New York: NY Times; 30 October 2005.
14. Mack N. Can boutique medicine save the health care system? Emergency Medicine News 2003;25:5, 34.

15. American Academy of Private Physicians [Homepage.] Available at http://www.aapp.org. Accessed 17 March 2010.

16. American Medical Association. Code of ethics. Opinion 8.055. Chicago, IL American Medical Association; 2003.

17. American Academy of Family Physicians. Retainer practices discussion paper. Kansas City, MO: American Academy of Family Physicians; 2006.

18. McWilliams JM, Meara E, Zaslavsky AM, Ayanian JZ. Use of health services by previously uninsured Medicare beneficiaries. N Engl J Med 2007;357: 143-53.

19. McWilliams JM, Zaslavsky AM, Meara E, Ayanian JZ. Impact of Medicare coverage on basic clinical services for previously uninsured adults. JAMA 2003; 290:757-64. 